\title{
Socio-Spatial Inequality in Education Facilities in the Concepción Metropolitan Area (Chile)
}

\author{
Helen De la Fuente ${ }^{1}$, Carolina Rojas ${ }^{1,2^{*}}$, María Jesús Salado ${ }^{3}$, Juan Antonio Carrasco ${ }^{1,4}$, \\ Tijs Neutens ${ }^{5}$ \\ ${ }^{1}$ Centre of Urban Sustainable Development CEDEUS, Concepción, Chile \\ ${ }^{2}$ Department of Geography, Universidad de Concepción, Concepción, Chile \\ ${ }^{3}$ Department of Geography and Geology, Universidad de Alcalá, Alcalá de Henares, Spain \\ ${ }^{4}$ Department of Civil Engineering, Universidad de Concepción, Concepción, Chile \\ ${ }^{5}$ Department of Geography, Ghent University, Krijgslaan, Ghent, Belgium \\ Email: *crojasq@udec.cl
}

Received September $13^{\text {th }}, 2013$; revised October $14^{\text {th }}, 2013$; accepted October $22^{\text {nd }}, 2013$

Copyright (C) 2013 Helen De la Fuente et al. This is an open access article distributed under the Creative Commons Attribution License, which permits unrestricted use, distribution, and reproduction in any medium, provided the original work is properly cited.

\begin{abstract}
In Concepción Metropolitan Area (CMA), the uneven geographical distribution of population, exacerbated by the recent spread of urban growth, has promoted a clear spatial inequity in the provision of quality educational facilities. The objective of this research is to systematically compare the 493 schools of existing educational opportunities in the CMA with the aim to evaluate the spatial equity in order to improve a most inclusive urban planning. Statistical and graphical analysis revealed that nearest units to the center of the metropolitan area (Concepción) had better conditions than the farthest with respect to studentsteacher ratio, teaching quality and academic outcomes assessment. This center-periphery pattern shows clearly the challenges to be faced in the CMA with respect to equitable access to quality educational resources.
\end{abstract}

Keywords: Spatial Equity; Inequality; Educational Facilities; Accessibility; Concepción Metropolitan Area (Chile)

\section{Introduction}

According to recent reports by the Organization for the Cooperation and Economic Development (OCDE), Chile is the country where private funding has increased weight in both primary and secondary education, and where the lowest degree of socioeconomic inclusion of the students within a school is found (OCDE, 2012). To this student segregation according to income level is added, presumably, a spatial segregation that according to free market laws, it concentrates best quality centers in urban sectors in which middle-high socioeconomic sectors predominate. This situation would be feeding a growing social polarization in which lower class groups located in peripheral areas have more difficult access to quality services and facilities (Sabatini \& Brain, 2008).

Research seems to corroborate this disparity of opportunities of social mobility. According to data from the Chilean Ministry of Education, for 2010 the best performance was concentrated in urban spaces occupied by middle higher classes, whereas less advanced schools, generally of public nature are found in spaces with high presence of lower income economic classes. In other words, a close relation seems to exist between the socioeconomic aspects of the families and the performance of an educational center (Ministerio de Educación, 2010; Oberty, 2007). In this situation, the question is how to describe statistically and geographically the spatial distribution of the educa"Corresponding author. tional centers, how to measure the accessibility of the school population to those centers, or how to establish the degree of spatial correlation between location of educational facilities and population strata according to their quality and level of income, respectively.

As study case, Concepción Metropolitan Area (CMA) is proposed. This city represents the second urban concentration in Chile, located in the coastal plains of the Biobío Region and subject to recent processes of population dispersion and urban growth, comparable to mid-size metropolitan areas of Latin America (Rojas et al., 2013). Despite the wide range of educational facilities in its 11 municipalities, coverage degrees and differential levels of spatial accessibility can be identified. Basically, in the most urbanized areas (Concepción and Talcahuano) relocation phenomena are of educational centers previously located in central sectors towards more distant places are being produced, thus favoring the use of private transport as mode of travel and the clustering of specific and homogeneous groups of population. On the other hand, least populated municipalities continue concentrating their schools in the urban center, whereas their urban growths are increasingly peripheral and distant, involving large displacements.

So, assuming that education represents a crucial factor to reduce inequities and improve the quality of life of the population (Fundación para la superación de la pobreza, 2006), this article pretends to be an essay on the integration of spatial distribution measures of educational facilities, with their own quality and 
socioeconomic situation indicators of the population close to every one of the schools. The aim is to enrich the assessment on the spatial equity in the distribution of the education opportunities and hence facilitate better and more inclusive planning.

The present work starts by briefly presenting the state of the issue and its geographic framework. Among the methods of statistical and cartographic analysis, the generation of an indicator of educational quality that summarizes the rate studentsteacher will be considered, as well as the learning results collected by the SIMCE (Measurement System of Quality Education of the Chilean Ministry of Education), and Moran's Local and Global Index, used to diagnose the spatial grouping of schools in CMA.

Results present a spatial diagnose of the educational quality in the area of study, as well as in the zones of low and high concentration of facilities. Finally both strengths and weaknesses of the investigation are discussed in order to improve the accessibility to a quality education, considering a more equitable spatial distribution (Ministerio de Educación, 2010).

\section{Principles of Equity, Equality and Spatial Justice in the Location of Facilities}

There is a way to understand these concepts beyond their merely textual meaning, mainly applied to social sciences and geography. These expressions arose on the basis of Radical Geography, which illustrates the insufficiency of the theoretical models of the Quantitative Geography, which were intended to explain both location of activities and land uses, to move towards measuring, quantifying and assessing geographic situations. It involves measuring the degree of injustice, equity or equality of distributions or spatial configurations (Moreno, 2007).

Some authors coincide on the close relation among Equality, Justice and Equity. Despite this, it is possible to obtain a differentiation, as explained by Bosque (2004), who pointed out that the meaning of equity can manifest itself as equality, but not necessary as synonyms, because equity is understood as justice, impartiality of treatment, opportunities, etc. Geographically, something is fair in the sense that distribution among areas has its own proportional differences and these differences are not seen as needs or difficulties, but acceptable for the population. Equality, on the other hand, starts from the basis that everyone must have the same opportunities, same health level, education and opportunities, creating a difficult application both in social and geographic terms, regarding that both people and spaces are different.

On the other hand, spatial justice can have two approaches: one that decreases differences among areas or distances, and one in which the required opportunity is reached. For the specific case of desirable facilities (Hospitals, Schools or other services), spatial justice is concerned are not unevenly distributed over the space, so there are no differences or. At least, they are not excessively big in the access of the population to these facilities (Flores, 2009). In the case of non-desirable facilities (industries, landfills), the issue is that the distances between population and facilities are not too dissimilar, so some people are not too affected, whereas others are not affected at all (Bosque \& Moreno, 2005).

Another author that recognizes similarities among terms of equality, justice and equity is Moreno (1999), who pointed out that justice corresponds to the "set of methods used by authori- ties to reduce inequalities among socio-spatial classes". On the other hand, equality would be sustained on democratic ideas and on egalitarian ideals of philosophy and alludes to the fact that a person has identical rights and obligations, so individuals must be treated in the same way, nevertheless it must be recognized that not all individuals are equal. For this reason, an assessment on situations, and profit sharing and disutility in a fair, impartial and equitable way must be carried out.

It is possible to make a distinction between arithmetic and proportional equality. Arithmetic equality is referred to a perfect equality, equality of treatment, where exactly the same amount of benefits is destined to everyone, regardless of the circumstances. Justice assumes an unequal distribution, so its aim is to improve the situation of the most disadvantaged. As postulated by Harvey (1977): "The geographic problem consists in elaborating a spatial organization mechanism that maximizes the perspectives of the most disadvantaged region". For Moreno, the terms of spatial equity and equality are almost synonyms, being differentiated from the justice, because ideal justice consists in the suppression of all disadvantages. In other words, justice encompasses both equality and equity. For this reason, justice mixes both social and spatial features. In other words, involves public authorities to attenuate inequalities and the notion of equality would be mixed with the scope of equity.

A similar version was presented by Pitarch Garrido (2000) for the elaboration of planning models of educational services, where five fundamental aspects must be considered, such as social equity, indicating that all public activity must be addressed to whole of the society excluding any discrimination on the basis of social differences. On this basis, education as public service must look for social equity as a right for every citizen. On the other hand, locational equity takes into account that the space always introduces inequalities and therefore, is a configurative factor, closely related to social equity.

\section{Educational System in CMA: Institutional and Geographic Framework}

The Chilean Educational system is divided into four levels: preschool education ( 4 to 5 years of age), primary education (6 to 15 years), secondary education (15 to 18 years) and higher education. This study is focused on the evaluation of the first three levels.

In theses levels the Chilean Ministry of Education have applied a number of assessment indicators, organized in five groups (Ministerio de Educación, 2008):

- Context indicators: They reflect the potential demand for educational services and the growth trend of such demand, as well as the relative size of the enrolment.

- Participation indicators: They are related to the access to education, participation and internal efficiency of the system. They are calculated by means of levels and include the net rate enrolment (total amount of students of the official age group in a specific level of primary or secondary education-6-13 and $14-17$ years of age, respectively, regarding the total population of that age group); and gross rate enrolment (total amount of students in a specific teaching level of primary or secondary education, in relation to the total amount of students for that education level). Age distribution by age and its growth rate show the trends in the different levels and institutions. Particularly, the distribution of the enrolment reflects important variations since 
1981, due to the incorporation of the subsidized education, which is pretending decentralizing the educational system.

- Resources indicators: Supplies possessed by schools in both monetary and human capital, i.e. teachers. They include the proportion between students and teachers, a kind of student load indicator assumed by the teacher. They are used to analyze the total expense in education.

- Result indicators: They measure the efficiency of the system. They include approval rates, as well as illiteracy and graduate rates.

- Indicators employability of students: In the workplace the participation of the work force and the unemployment rate are measured, because this is higher for the younger sector of the population ( 25 to 29 years) than for the total population ( 25 to 64 years). In addition, there is a direct relation between the educational attainment and unemployment (Ministerio de Educación, Departamento de Estudios y Desarrollo de la División de Planificación y Presupuesto, 2008).

Additionally, the Chilean Ministry of Education carries out the SIMCE tests (acronym in Spanish for the Measurement System of the Quality of Education) in order to obtain national data on learning outcomes in the so-called Fundamental Objectives and Minimum Required Contents (OF-CMO). Table 1 presents the outcomes of SIMCE 2010, for the entire country and for Biobío Region as a whole. It can be observed that the regional outcomes are located around the average (slightly below in the case of primary education and slightly above in the case of secondary education). Later, in Table 2 the outcomes for CMA can be observed, disaggregated for municipalities.

Concepción Metropolitan Area (CMA) located in Central South Chile, is a functional and hierarchical territory formed by 11 municipalities, with a population of about one million inhabitants. The main articulator centers are Concepción and Talcahuano and the other municipalities or sub enters are Coronel, Chiguayante, Hualqui, Lota, Penco, San Pedro de la Paz, Santa Juana, Florida and Tomé. In the CMA important urban transformations have been produced in the last years, such as commercial and the development of facilities nuclei of regional importance, as well as a sustained improvement in the accessibility conditions and, in general, in transport infrastructures (Figure 1). In 2011 there were 493 schools in CMA, with a predominance of private subsidized schools (40.7\%). Public schools represent $38.5 \%$ and private schools are only $5.4 \%$. Table 3 presents these data along to the population size, disaggregated by municipality.

Regarding the general status of education in the CMA, the municipality with the highest schooling is Concepción, with an average of 10.7 years (CASEN, 2006). In the case of enrolment for public, subsidized and private schools, most of them also belong to Concepción, with 54,596 students in 2010, according to Annual Plan of Municipal Educational Development (PADEM, 2011). On the other hand, the illiteracy rate presents the highest values in municipalities of rural environment, such as Santa Juana and Hualqui, whereas Concepción, Chiguayante and Talcahuano have the lowest rates, with circa $2 \%$ of the population (CASEN, 2006).

\section{Data and Methods}

\section{Selected Indicators}

In order to describe the distribution of educational facilities
Table 1.

Results SIMCE, national and regional level.

\begin{tabular}{|c|c|c|c|c|c|}
\hline \multirow{2}{*}{$\begin{array}{c}\text { Educational } \\
\text { level }\end{array}$} & \multicolumn{3}{|c|}{ National } & \multicolumn{2}{|c|}{ Biobío Region } \\
\hline & Evaluation & Score & $\begin{array}{l}\text { Average } \\
\text { score }\end{array}$ & Score & $\begin{array}{c}\text { Average } \\
\text { score }\end{array}$ \\
\hline $\begin{array}{c}4^{\text {th }} \text { Primary } \\
\text { school }\end{array}$ & $\begin{array}{c}\text { Reading } \\
\text { Math education }\end{array}$ & $\begin{array}{l}262 \\
253\end{array}$ & 257.5 & $\begin{array}{l}250 \\
257\end{array}$ & 253.0 \\
\hline $\begin{array}{c}8^{\text {th }} \text { Primary } \\
\text { school }\end{array}$ & $\begin{array}{c}\text { Reading } \\
\text { Math education }\end{array}$ & $\begin{array}{l}252 \\
260\end{array}$ & 256.0 & $\begin{array}{l}252 \\
248\end{array}$ & 250.0 \\
\hline $\begin{array}{c}2^{\text {nd }} \\
\text { high school }\end{array}$ & $\begin{array}{c}\text { Reading } \\
\text { Math education }\end{array}$ & $\begin{array}{l}255 \\
250\end{array}$ & 252.5 & $\begin{array}{l}263 \\
252\end{array}$ & 258.0 \\
\hline
\end{tabular}

Note: Source: Ministry of Education, 2010.

Table 2.

Educational facilities in CMA (according to SIMCE results).

\begin{tabular}{|c|c|c|c|c|c|}
\hline \multirow{2}{*}{ Province } & \multirow{2}{*}{ Commune } & \multirow{2}{*}{$\begin{array}{c}\text { Numbers of } \\
\text { schools }\end{array}$} & \multicolumn{3}{|c|}{ According to perfomance } \\
\hline & & & High & Medium & Low \\
\hline \multirow{12}{*}{ Concepción } & Concepción & 68 & 26 & 31 & 8 \\
\hline & Talcahuano & 46 & 9 & 26 & 12 \\
\hline & San Pedro de la Paz & 29 & 7 & 11 & 9 \\
\hline & Chiguayante & 29 & 5 & 17 & 4 \\
\hline & Penco & 19 & 1 & 16 & 1 \\
\hline & Tomé & 26 & 4 & 15 & 2 \\
\hline & Coronel & 35 & 4 & 23 & 8 \\
\hline & Lota & 17 & 1 & 10 & 1 \\
\hline & Hualpén & 25 & 13 & 14 & 6 \\
\hline & Hualqui & 17 & 11 & 5 & 3 \\
\hline & Santa Juana & 20 & 1 & 4 & 6 \\
\hline & \multicolumn{5}{|c|}{ *High: >283 points; Medium: 237 - 282; low: $<283}$. \\
\hline
\end{tabular}

in the area of study, four dimensions of interest were selected, with indicators that could measure them: Dispersion (standard deviation ellipse), concentration (neighborhood index), spatial inequality (Sargent Florence Quotient) and supply-demand relation (indicator of accumulated opportunities). Second, a synthetic indicator of educational quality composed of variables considered representative is proposed: students-teacher ratio, teacher evaluation and SIMCE results. Both indices and indicators used in the study are detailed as follows:

\section{Standard Deviation Ellipse}

It allows assuming the main spatial characteristics of a set of geographic entities: central tendency, dispersion and directional trends. Its core shows the central tendency of that set of entities; its major axis is extended towards the maximum dispersion direction and its minor axis indicates the degree of linearity of the distribution. Given the fact that it can be mathematically demonstrated that the maximum dispersion axis in a dot structure always forms a straight angle with the minimum dispersion axis, an ellipse constitutes an adequate representation form for 
Table 3.

Census districts CMA.

\begin{tabular}{|c|c|c|c|c|c|c|c|}
\hline Code & Name & Code & Name & Code & Name & Code & Name \\
\hline 0 & Intendencia & 39 & Bannen & 20 & Plaza Perú & 59 & San Vicente \\
\hline 1 & Liceo de Hombres & 40 & Lota Bajo & 21 & Observatorio & 60 & Estadio \\
\hline 2 & La Cárcel & 41 & Cementerio & 22 & Larenas & 61 & Huachipato \\
\hline 3 & Plaza España & 42 & Colcura & 23 & Pedro de Valdivia & 62 & Ramuntcho \\
\hline 4 & Estación Central & 43 & Penco & 24 & Palomares & 63 & Hualpencillo \\
\hline 5 & Cerro Amarillo & 44 & Fábrica & 25 & Lo Pequén & 64 & Carriel \\
\hline 6 & Plaza Cruz & 45 & Lirquén & 26 & Municipalidad & 65 & Las Salinas \\
\hline 7 & Cementerio & 46 & Margaritas & 27 & Villa Mora & 66 & Barranquilla \\
\hline 8 & Laguna Redonda & 47 & Batro & 28 & Schwager & 67 & Zunico \\
\hline 9 & Pajonal & 48 & Boca Sur & 29 & Buen Retiro & 68 & Estadio Higueras \\
\hline 10 & Manuel Rodríguez & 49 & Los Acacios & 30 & Corcovado & 69 & San Miguel \\
\hline 11 & Escuela Argentina & 50 & San Pedro & 31 & Escuadrón & 70 & Club Hípico \\
\hline 12 & General Cruz & 51 & Lomas Coloradas & 32 & Lonco & 71 & Bremen \\
\hline 13 & Estación Tucapel & 52 & Santa Juana & 33 & Matadero & 72 & Cerro Verde \\
\hline 14 & Lo Méndez & 53 & El Portón & 34 & Fábrica & 73 & El Puerto \\
\hline 15 & La Toma & 54 & Valdivieso & 35 & Chiguayante & 74 & Ralihue \\
\hline 16 & La Pólvora & 55 & Cerro Fuentes & 36 & La Leonera & 75 & El Morro \\
\hline 17 & Población Baquedano & 56 & La Aduana & 37 & Hualqui & 76 & Dichato \\
\hline 18 & Plaza Condell & 57 & Cerro Buenavista & 38 & Lota Alto & & \\
\hline 19 & Hospital & 58 & Tumbes & & & & \\
\hline
\end{tabular}

Note: Source: INE 2002.

such dispersion by providing a perceived "mean" location and thus it allows perceiving the whole systematic delocation of the places.

\section{Neighborhood Index}

Neighborhood index or nearest neighbor analysis is simply the calculation of the average distance divided by the expected average distance to the nearest neighbor, in the case of a random disposition. If the index is greater than 1 , dispersion is the tendency. On the contrary, the pattern will show a conglomerate distribution and its calculation results from the following:

$$
R=\frac{\bar{\alpha}_{o b s}}{\alpha_{r a n}}
$$

where $R$ is the neighborhood index, $\alpha_{o b s}$ is the observed distance to the nearest neighbor and $\alpha_{\text {ran }}$ is the expected average distance to the nearest neighbor, in a random dot arrangement. Neighborhood index can have values between 0 , which indicates a fully grouped structure and 2.15 , which indicates a fully disperse structure. This indicator provides a very useful descriptive measure of specific structures, especially for identifying the increase or decrease of both dispersion or grouping of a structure (Ebdon, 1982). The index has used the centroid points of each census unit population.

\section{Sargent Florence Quotient}

This index basically measures the degree of inequality among territories. The interpretation considers with value 1 to an egalitarian country condition. On the other hand, values higher than 1 correspond to a surplus of schools. Finally, values lower than 1, correspond related to a deficit of educational institutions. In the study carried out by Fuenzalida (2010) on distribution of hospitals, it is concluded that this index is an unavoidable complement for the comprehension of the spatial inequalities. Table 4 clarifies its interpretation, being established the numerical thresholds to facilitate the assessment of results.

The index is applied in the following equation:

$$
C L_{i}=\frac{O_{i} / \sum_{i=1}^{n} O_{i}}{d_{i} / \sum_{i=1}^{n} d_{i}}
$$

where $C L_{i}=$ location quotient of the territorial $i$ subunit; $i \cdots n=$ subunits of the $j$ set; $O_{i}=$ educational service offering in $i$ subunit and $d_{i}=$ educational service demand in $i$.

In this case, $i$ subunits are represented by the census districts 


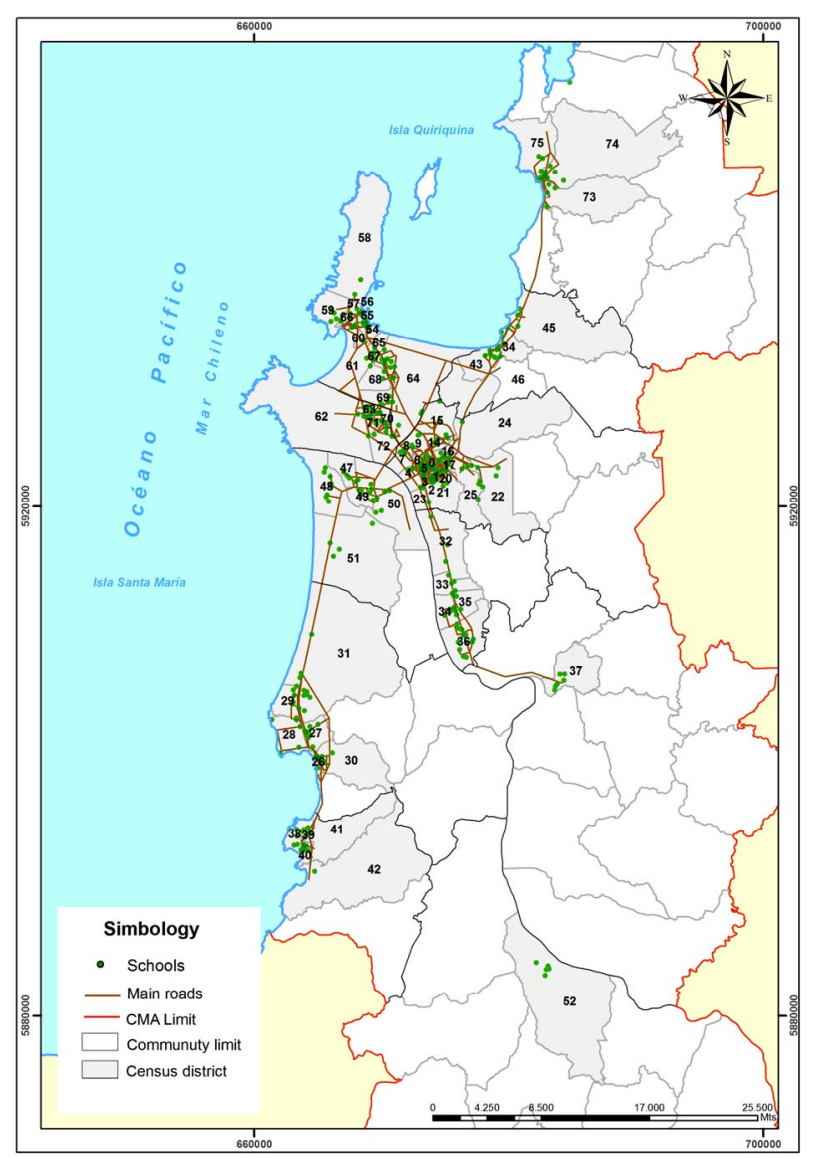

Figure 1.

Concepción Metropolitan Area.

of every municipality of CMA, in which $O_{i}$ educational offering corresponds to the sum of the students registered by the Ministry of Education that attend each school in the $i$ district. On the other hand, the demand variable is referred to the potential population to attend, whereas the demand variable is related to the potential population that attends to an educational facility in the subunit. In other words, they correspond to people between 0 to 17 years, according to data from Census (2002). Subsequently, results obtained from the index are plotted in five main categories. These are: important deficit, moderate deficit, moderate surplus, important surplus and country condition (Table 5).

Hence, a value close to 1 will mean that the proportion of the offering in the $i$ subunit respect to the total CMA is similar to the proportion of demand in $i$ respect to the total. Values higher than 1 indicate that in the $i$ subunit there is a relative oversupply respect to the resident demand; and values lower than 1 indicate that there is a deficit in the supply respect to the demand registered in I, which is greater as farther away from the unit.

\section{Resident Population Indicator in an Area of Specific Radius/Indicator of Accumulated Opportunities}

Although several limitations and possible improvements have been pointed out (Bisonnette et al., 2012; Chen et al., 2012; Langford et al., 2008), the method called Two Step Floating Catchment Areas (2SFCA) has been frequently used in the recent literature on the assessment of spatial inequities in the
Table 4.

Qualitative and quantitative classification of educational quality indicators.

\begin{tabular}{ccccc}
\hline $\begin{array}{c}\text { Partial } \\
\text { indicators }\end{array}$ & Weight & Low quality & Medium quality & High quality \\
\cline { 2 - 5 } & $\mathbf{- 1 \leftarrow}$ & $\leftarrow \mathbf{0 \rightarrow}$ & $\boldsymbol{\rightarrow 1}$ \\
\hline $\begin{array}{c}\text { Student- } \\
\text { Teacher ratio }\end{array}$ & 2 & $>34$ students & $17-34$ students & $<17$ students \\
$\begin{array}{c}\text { Teacher } \\
\text { evaluation }\end{array}$ & 3 & $\begin{array}{c}\text { Satisfactory and } \\
\text { basic performance }\end{array}$ & $\begin{array}{c}\text { Competent } \\
\text { performance }\end{array}$ & $\begin{array}{c}\text { Outstanding } \\
\text { performance }\end{array}$ \\
SIMCE results & 5 & $\begin{array}{c}\text { Achitial } \\
\text { level }\end{array}$ & $\begin{array}{c}\text { Intermediate } \\
\text { achievement level }\end{array}$ & $\begin{array}{c}\text { Advanced } \\
\text { achievement } \\
\text { level }\end{array}$ \\
\hline
\end{tabular}

Table 5.

Sargent Florence assessment.

\begin{tabular}{cc}
\hline Level of locator coeffciencient & Value \\
\hline Important deficit & $<0.49$ \\
Moderate deficit & $0.50-0.99$ \\
Moderate surplus & $1.01-1.87$ \\
Important superplus & $1.88-2.73$ \\
Country situation & 1 \\
\hline
\end{tabular}

Note: Source: Fuenzalida, 2010.

distribution of public facilities (Cervigi et al., 2008; Chen et al., 2012; Gualiardo, 2004; Luo, 2004; Luo \& Qi, 2009; Luo \& Whippo, 2012; Wang, 2012). The first step establishes a buffer around every supply center and it counts how much population resides inside them. The second step the buffer is sketched from every point of demand and the centers or facilities located inside the center are added.

Both start from the delimitation of an influence area of determined extent from these points. If these points represent the supply, it can be accounted the volume of resident population within such area, besides quantifying the population covered by the service. In this case, the service is educational. The Geographic accessibility of the facility is also measured (Gutiérrez \& García, 2002). If the points that originate the influence area represent the demand, the number of available schools or hospital beds can be quantified within that range of distance from each demand point, an indicator of accumulated opportunities will be used as an accessibility measure (Salado, 2012).

In any case, in order to use one and another, it is necessary to consider at least three elements: points of supply, distribution of population (potential demand) and the gap among the potential demand of the points of supply, according to areas of influence.

In order to determine the areas of influence, two methods that consider the location of educational centers have been taken into account. The first method consists in modeling different areas of influence or buffers of 500 and $1000 \mathrm{~m}$, ranges commonly used as more accessible (Ramírez, 2008; Villanueba, 2010; Sabuda, 2007; Yi, 2004) and Pizzolato, Broseghini, \& Noguera, 2002). The second method uses areas of influence from the análisis through Thiessen polygons. It must be noted that both GIS operations are carried out by means of the ArcGis 
software. Later, buffers are intersected with the area of influence from Thiessen polygons (geometric construction of the schools).

For the calculation of the population variable within the range of geographic accessibility (buffers intersected with Thiessen polygons), an inconvenient is presented by how determining the amount of potential population between 0 and 17 years, because of its irregular distribution, which many times covers not completely the census blocks. This information is required to determine the approximate number of people covered by the educational service. Therefore, for the solution to this problem the method proposed by Gutiérrez, Pinto \& Gómez (2000) is used. This method is nothing but the ratio between the total population of the block and the population covered by the area of influence, as detailed in the following equation:

$$
P=\sum_{i=1}^{n}\left[p i+\sum_{f=1}^{n}(p j *) \frac{a j}{a j}\right]
$$

Being $P=$ total population estimated in the area of influence of any facility; $i \cdots n=$ sectors entirely included in the coverage area; $p i=$ population entirely included in the coverage area; $j \cdots m$ $=$ sectors partially included in the coverage area; $p j=$ population of the $j$ sector; $a j=$ area of the $j$ sector which is within the area of influence; and $a j=$ area of the $j$ sector.

\section{Educational Quality Indicator (EQI)}

This synthetic indicator summarizes three partial indicators. From these results, a qualitative evaluation scale was carried out (low, middle and high quality), as well as a quantitative scale (between -1 and 1). Both balance of these partial indicators and the definitive classification are presented in Table 5.

- Student-Teacher ratio: It is equivalent to the number of students in relation to the total amount of teachers according to education level, administrative dependency, region and geographic area. Carried out by the Chilean Ministry of Education, it allows studying the endowment of teacher per student and outlines the school situation per school.

- Teacher evaluation: The Ministry of Education carries out the performance evaluation of school teacher, establishing four degrees: outstanding (it indicates a professional performance that clearly and consistently stands out with respect to expected), competent (proper professional performance, it fulfils the requirements), basic (it fulfils with what is expected in the indicator, but irregularly), and unsatisfactory (it presents clear weaknesses in the teaching performance).

- SIMCE results (of learning outcomes in Fundamental objectives and Minimum Required Contents): Disaggregated results are presented in Table $\mathbf{l}$. This is the indicator granted with the greatest weight, because it counts on a methodologically solid system, it is widely used as tool for education policies and it has been in use for long time.

From every variable, a qualitative evaluation scale is performed, with variables such as: High, Medium and Low quality. On the other hand, a quantitative sale was also performed, assigning minimums that range from -1 to 1 as maximum. The evaluation scale used to measure the descriptive correlation statistics of variables is presented in Table 5. This scale fulfills with the condition of being a scale of comparable values that allows assessing different factors, variables or criteria, inde- pendently of the method to be used (Moreno, 1999).

The assessment favors the fact that all values are expressed in a comparable scale of values ( -1 to 1$)$. Therefore, by means of a simple calculation procedure the proportion applied through maximum and minimum values of each variable under study is applied, as observed as follows:

$$
X=\left[\left(\frac{2}{X_{\min }-X_{\max }}\right)\left(Y<-X_{\min }\right)\right]-1
$$

where $X$ corresponds to the value assigned by the scale, $X_{\min }$ is the minimum value of the data set, $X_{\max }$ is the maximum value of the data set, and $Y$ represents the data value to convert.

By means of this equation it is possible to convert all continuous data into a scale of values between -1 and 1 . Thus, a data matrix or basic input for the construction of educational quality index is obtained.

The synthetic index, product if every one of the dimensions (Teacher evaluation, SIMCE test and teacher student ratio) gives more weight to the SIMCE results, then to the teacher evaluation and finally to the student teacher ratio. This proportional order is given to the fact that for the Chilean Ministry of Education. SIMCE has greater "legitimacy and credibility". This test has allows focusing the attention of the public opinion and the teachers into the learning results, by means of a methodologically solid system, as well as widely used tool for educational policies, making clear that this is a reliable indicator in time. In Table 6 three indicators of educational quality and their different relative weights for obtaining the synthetic index of educational quality can be observed. The index allows a first approach to the distribution of the phenomenon under study, assuming that every spatial unit have weighted values of each variable, being 10 the maximum value of the scale and representing an educational quality of excellent level. On the other hand, -10 is the minimum value, demonstrating the opposite situation, i.e. an education with multiple deficiencies (Table 6).

\section{Geostatistical Analysis}

The result from the previous indicators was later assigned to cells in a $100 \times 100 \mathrm{~m}$ grid (the size of the grid has been established regarding that the average size of a census block, in the CMA fluctuates around $10,000 \mathrm{~m}^{2}$ ). The aim of this assignment was to find out if the distribution of the results corresponded to a condensed, scattered or random pattern by GeoDa Software. In order to achieve this, a spatial auto-correlation analysis that studies the variation mode of the thematic values among the different points of the space is carried out (Góngora Gómez, 2007).

Spatial auto-correlation reflects the degree in which objects or activities in a geographic unit are similar to other objects or

Table 6.

Weighting of quality indices.

\begin{tabular}{cc}
\hline Variable & Ponderación \\
\hline SIMCE & 5 \\
Evaluación docente & 3 \\
Tasa Alumno profesor & 2 \\
Total & 10 \\
\hline
\end{tabular}


activities in close geographic units (Goodchild \& Haining, 1992). Basic property of spatial auto-correlated data is that values are not random in space. In other words, data values are spatially correlated each other and become redundant (Lee \& Wong, 2001). This kind of models supposes that finding a specific observation in a point of an area it is possible to find similar observations in points close to it. On the contrary, distant points would have totally dissimilar characteristics.

Specifically, the Moran's Statistical Global index (I Moran) was applied. This index determines the kind of grouping existing between neighbor spatial units in order to obtain some known distribution model, or to study the spatial segregation of a characteristic. The complexity of the problem increases as a result of possible multidirectional interdependencies that may arise in the space. Its formulation is as follows:

$$
I=\frac{n}{S} \times \frac{\sum_{i=1}^{n} \sum_{j=1}^{n} W_{i j} Z_{i} Z_{j}}{\sum_{i=1}^{n} Z_{i}^{2}}
$$

where $n$ is the number of geographic observation units, $w_{i j}$ are the elements of a binary contiguity matrix, $x$ is the attribute of this variable and the mean of the cross product.

The measurement of a correlation with the same variable has in different spatial contiguous units in a horizontal perspective, originates one out of these three possibilities:

- Positive spatial auto-correlation: neighbor spatial units present close values and indicate for the spatial units a tendency to grouping.

- Spatial negative correlation: Neighbor spatial units present very dissimilar values and indicate for the spatial units a tendency to dispersion.

- No correlation: any of the above situations take place. Therefore, values of neighbor spatial units present values randomly produced.

Moran's index is grounded in an auto-covariance model and, after the mean and the variance, is the most important property of any geographic variable. Unlike the previous ones, it is explicitly linked to spatial patterns. These observations can be discrete or continuous and they may be associated to a point on a specific surface, or associated to a surface on which a partition has been performed. This partition may be regular or irregular and commonly recognized as reticule (López Hernández \& Palacios Sánchez, 2000).

In general, geographic data are presented in a continuous map. The contiguity respect to the central location (e) can be defined in three ways, by means of chess terminology:

1) Rooks criteria: cells b, d, f and h are considered adjacent to the location of "e".

2) Bishops criteria: cells a, c, g and i would be considered neighbors to the location " $\mathrm{e}$ ".

3) Queen criteria: It combines the above two and thus cells a, $\mathrm{b}, \mathrm{c}, \mathrm{d}, \mathrm{f}, \mathrm{g}, \mathrm{h}$ and i would be considered contiguous to "e".

The kind of contiguity on which the work was carried out was Rooks, one of the most used, because of its simplicity (Celemin, 2009).

Outcomes from this index vary from -1 to 1 , representing minimum (maximum dispersion) and maximum (maximum concentration) correlations, respectively. Zero means totally random spatial pattern. In order to know if an auto-correlation is significant, a null hypothesis test is carried out, checking whether the spatial configuration of the variable occurs randomly or it responds to a spatial pattern. In other words, if the assumptions of model whether or not are satisfied from the estimation if a sampling statistic significantly differs from the randomly expected. This test is carried out by locating Moran's coefficient inside a normal probability curve (Buzai \& Baxendale, 2008).

In order to perform this kind of tests, both null and alternative hypotheses must be clearly formulated. When working on socio spatial projects, as null hypothesis the following claim is considered: "The spatial configuration is randomly produced and as alternative hypothesis, the opposite claim: the spatial configuration is NOT randomly produced" (Celemin, 2009). Once both hypotheses have been established, the significance level $(\alpha)$ must be defined. This indicates the probability for the null hypothesis to be rejected. In other words, if the occurrence probability of a particular value obtained in a test is equal or lower than $\alpha$, the null hypothesis is rejected and the alternative hypothesis is accepted. Habitually, the significance level is chose according to the importance of the problem. In the sociospatial analysis is usually 5\% (0.05) and 1\% (0.01) (Buzai \& Pineda, 2007).

$P$-value is the result reported by the hypothesis test. Then, if a significance level of 0.05 is established in general, $p$-value presents values lower than 0.05 . This allows rejecting the null hypothesis and accepting the alternative hypothesis, taking into account that with this decision there is a risk of making a mistake in $5 \%$ of the cases. On the contrary, if the $p$-value presents results over 0.05 , the alternative hypothesis is not accepted, because the risk on the decision exceeds the established limit, and the null hypothesis must be accepted. In other words, the "spatial configuration is occurs randomly".

Moran's I value represents the spatial correlation degree either univariate or bivariate of variables and every point of the diagram represents a specific different spatial unit, with $\mathrm{X}$ and $\mathrm{Y}$ coordinates. In the case of a univariate correlation, on the $\mathrm{X}$ axis of the diagram, standardized values of the considered variables and on the $\mathrm{Y}$ axis standardized values of "average" values of the neighbor spatial units for such variable will be placed. Moran's I index value is equivalent to the slope of the regression line. The slope of the line represents the association degree between the variable considered on the horizontal axis and the values of the variable on the vertical axis, in relation to the location of their neighbors (Sabuda, 2007).

\section{Description and Analysis of Results}

\section{Spatial Distribution of the Educational Facilities}

The standard deviation ellipses reveal a location model concentrated in every column due to a greater proportion of schools in urban centers consolidated in the cities of the CMA (Figure 2). This map evidences that out of the ellipses area lower quality schools are found, especially in the cities of San Pedro de la Paz, Coronel and Penco. Regarding the directional tendency of the ellipses, these are ruled by a linear organization pattern (Penco, Talcahuano, Coronel and Chiguayante), providing an elongated and disperse shape leaned towards the most hierarchic urban center, which corresponds to Concepción.

In relation of the spatial indicators, the neighborhood analysis, the average distance observed between centers is 369.2 meters, a short distance indeed that represents no obstacle to access to a school by walking (Gutiérrez \& García, 2002). The main difficulty is given by values far from average. Values far from average are constituted by distances among private 


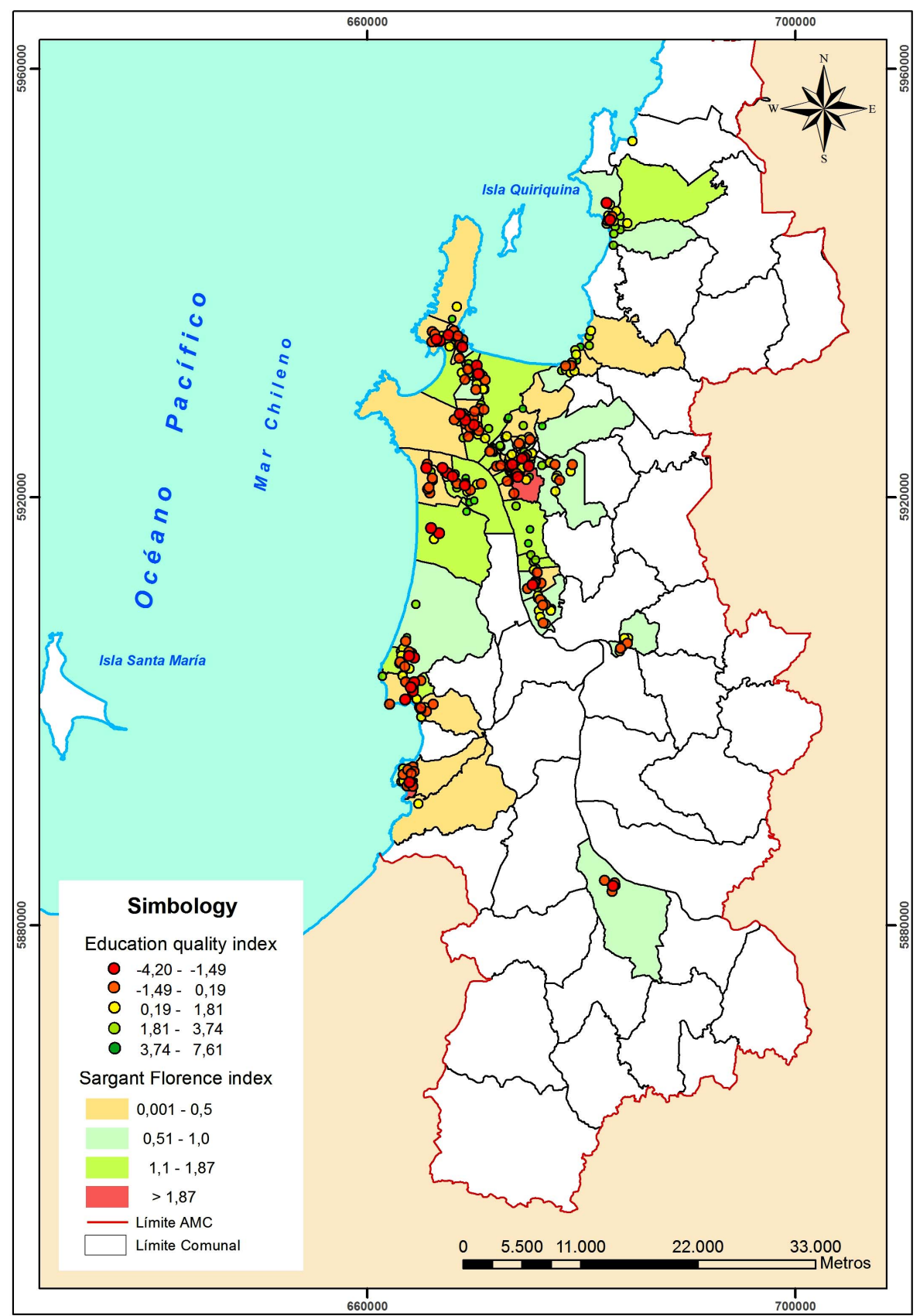

Figure 2.

Distribution of educational quality index and Sargent Florence Quotient in CMA (Source: Own).

schools, due to their tendency of being located in peripheral areas. On the contrary, minimum distances are given among municipal schools. The expected distance, product of the density of points in a specific area is 369.4 meters. Therefore, the neighborhood index offers a result of $1005 \mathrm{~m}$ that can be interpreted as a random pattern far from both ends ( 0 and 2.15).

Index of accumulated opportunities (Table 7) shows the population represented by centroids of census blocks which are covered by three ranges of buffers distance:

Less than 500 meters (Pedestrian proximity distance to facilities (Gutiérrez García, 2002) low density census block are found (50 inhabitants). Exceptions are presented in Hualpén,
Chiguayante Sur and in Agüita de la Perdiz sector in Concepción. Total population grouped in this range reaches 201,438 inhabitants for CMA (40.9\% coverage). When people between 0 and 17 years of age, the coverage increases up to 213,869 inhabitants.

In the second service ring (500 to 1000 meters) census blocks with more than 50 inhabitants are located, reaching more than 100 inhabitants per sample unit (census blocks). Most distant sectors are Collao Sector, Barrio Norte, Tucapel Bajo, Chepe Hill and Agüita de la Perdiz. These places are located approximately $1 \mathrm{~km}$ from the nearest school and in some cases, the facilities are low quality. In San Pedro de la Paz the disadvan- 
Table 7.

Index of accumulative opportunities.

\begin{tabular}{|c|c|c|c|c|c|c|}
\hline \multirow[b]{2}{*}{ Commune } & \multicolumn{2}{|c|}{ Less than $500 \mathrm{~m}$} & \multicolumn{2}{|c|}{500 to $1000 \mathrm{~m}$} & \multicolumn{2}{|c|}{ More than $1000 \mathrm{~m}$} \\
\hline & $\begin{array}{l}\text { Covered population } \\
\left(\mathrm{N}^{0} \text { inhabitants }\right. \\
\text { within ring) }\end{array}$ & $\begin{array}{l}\% \text { covered } \\
\text { population from } 0 \\
\text { to } 17 \text { years of age }\end{array}$ & $\begin{array}{l}\text { Covered population } \\
\left(\mathrm{N}^{0} \text { inhabitants }\right. \\
\text { within ring })\end{array}$ & $\begin{array}{c}\% \text { covered } \\
\text { population from } 0 \\
\text { to } 17 \text { years of age }\end{array}$ & $\begin{array}{l}\text { Covered population } \\
\left(\mathrm{N}^{0} \text { inhabitants }\right. \\
\text { out of range })\end{array}$ & $\begin{array}{c}\% \text { covered } \\
\text { population from } 0 \\
\text { to } 17 \text { years of age }\end{array}$ \\
\hline Concepción & 40786 & 55 & 16169 & 22 & 16574 & 23 \\
\hline Talcahuano & 42231 & 68 & 6947 & 11 & 12900 & 21 \\
\hline San Pedro de la Paz & 20181 & 52 & 5694 & 15 & 12893 & 33 \\
\hline Chiguayante & 21753 & 53 & 6042 & 15 & 13017 & 32 \\
\hline Penco & 10318 & 58 & 2720 & 15 & 4837 & 27 \\
\hline Tomé & 9515 & 68 & 2489 & 18 & 2026 & 14 \\
\hline Coronel & 28455 & 76 & 4114 & 11 & 4786 & 13 \\
\hline Lota & 12643 & 69 & 2455 & 13 & 3190 & 17 \\
\hline Hualpén & 22353 & 66 & 2520 & 7 & 8985 & 27 \\
\hline Hualqui & 3665 & 62 & 748 & 13 & 1535 & 26 \\
\hline Santa Juana & 1979 & 64 & 526 & 17 & 587 & 19 \\
\hline AMC & 213879 & 62 & 50424 & 15 & 81330 & 24 \\
\hline
\end{tabular}

taged sectors are Candelaria, San Pedro de la Costa and Boca Sur. Population between 0 and 17 years of age covered in this ring is significantly lower ( 81,330 inhabitants for the CMA), totaling a coverage of 81,330 people.

Population without coverage (outside the 1000 meters threshold) is represented by 139,549 people, or $38.02 \%$. Per municipalities, Coronel leads with the greatest amount of people outside the coverage area, followed by Concepción and San Pedro de la Paz.

The exercise of quantifying the population between $0-17$ years of age covered the educational service shows the greatest population concentration around the main rings (206,303 inhabitants), which represents $76.46 \%$ of the total population. This number is encouraging, because most of the people have access to a school, but the obstacles lie on imbalances in the educational unit, motivating the students to both search and mobility in order to access to better opportunities. In other words, students within the immediate fringes can cover distances over than 1000 meters, product of these differences in education. This lack of opportunities makes the spatial equality conditions more difficult, originating unacceptable imbalances (Escolano et al., 2005).

As we have mentioned in the previous section, Sargent Florence Quotient estimates deficit or surplus of the educational service according to the supply offer proportion. As it can be seen in the map from Figure 3, districts with greater facilities deficit (values lower than 0.49 ) belong to the municipalities of Talcahuano, Penco, Lota and Coronel, in which schools with lower academic performance predominate (Table 6). On the other hand, the surplus (values greater than 1.88) is presented in districts within the municipalities of Talcahuano and Concepción, which have a correspondence of values lower values of educational quality.

Definitively, in CMA districts that lack educational facilities and in a situation of important or moderate deficit correspond to $31 \%$ and $18 \%$ of the population, respectively, whereas the moderate surplus corresponds to $24 \%$ and the important surplus is $27 \%$. The highest number corresponds to districts within the "important deficit" category (0.001), which indicates a notorious spatial inequity, because the contrast between the district with the highest deficit and the district with the greatest surplus has amplitude of 14.7 units.

\section{Spatial Distribution of the School Quality}

Once the results of the educational quality indicator have been placed on the $100 \times 100 \mathrm{~m}$ grid (Figure 3) it can be observed with greater clarity the tendency to concentration of the highest values in the areas close to the urban nucleus Concepción - Chiguayante - San Pedro de la Paz, in contrast to the rest of the urban sectors of the CMA.

The spatial auto-correlation analysis corroborates the previous qualitative interpretation. In Figure 3 it can be seen how clusters that concentrate good quality education (represented in live red) are found in the following sectors: Lomas de San Andrés, Santa Sabina, new Chiguayante, airport Sector, road to Penco, Huertos Familiares and Villa San Pedro. All of them have high-high value. In other words, high proportion of the indicator in the reference grid close to other spatial unit that also counts on high proportion of the same indicator. In an opposite situation are the low-low clusters (deep blue areas in Figure 4), that group low quality education and located in areas such as: San Pedro de la Costa, Boca Sur, Michaihue, Candelaria, parte de Lomas Coloradas, Cerro Cornou and Hualpencillo, along to the industrial zone, much of Coronel, Lota, Santa Juana, Hualqui and the Frutillares sector in Tomé. Places in white represent an absence of auto-correlation of the variable. Therefore, they are not significant to the study. 


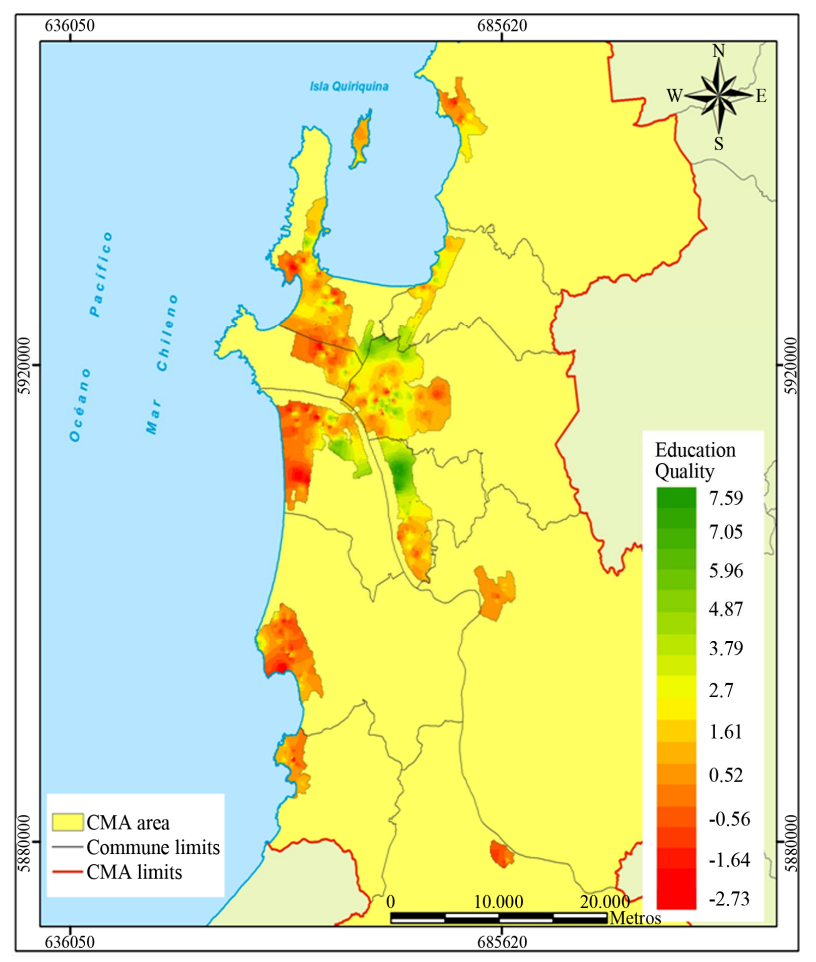

Figure 3.

Distribution of educational quality in the CMA (Source: Own).

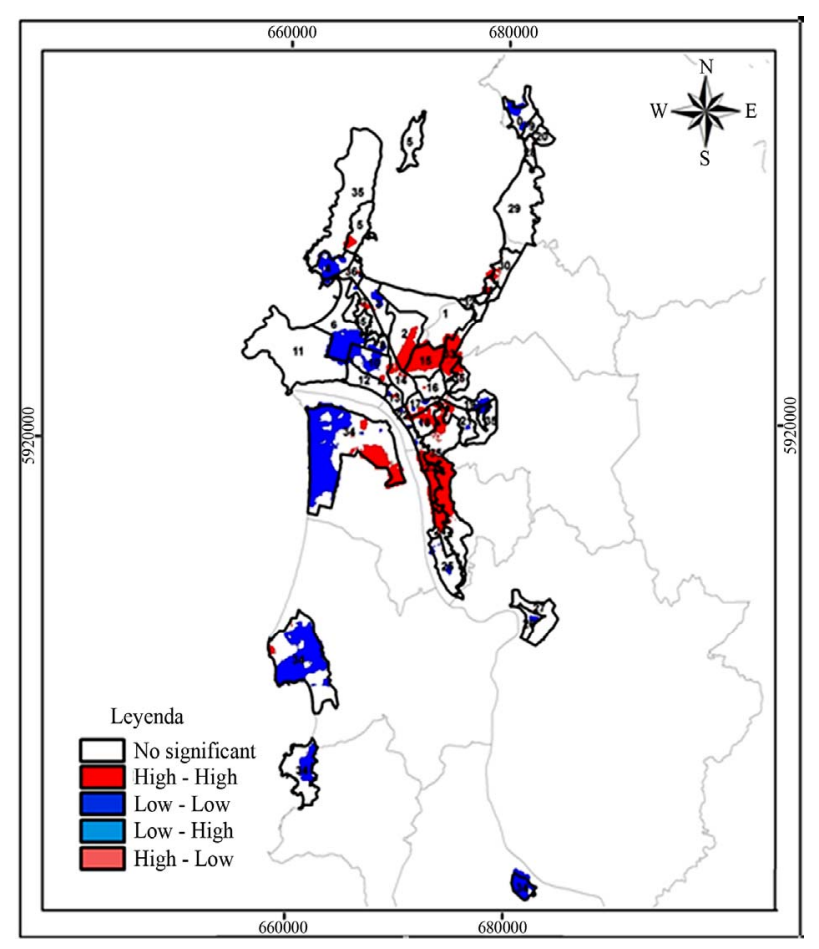

Figure 4.

Cluster of educational quality in the CMA (Source: Own).

Regarding the significance degree of the analysis, this is justified with the map that represents the distribution of the $p$ value in the CMA (Figure 4). This map reveals a significance of 0.05 , so the null hypothesis on the random distribution of the variable in the territory is rejected and the alternative hypothesis is accepted (this variable does not present a random distribution, but it corresponds to a particular spatial pattern).

The index clearly shows how the best schools are located in zones of high economic level. The spatial evidence is enhanced with results from the Chilean Ministry of Education, where in both reading and math tests, the percentage of students with scores over 300 points increases as the socioeconomic level increases. However, in all groups there are students with scores over 300 points. For instance, from the students of the low group that undertakes both reading and Math tests, $5 \%$ and $4 \%$, respectively obtain scores that exceed 300 points.

Results from every one of the variables analyzed by means of Moran's univariate spatial auto-correlation show the relation between educational quality and location. Specifically, results from Moran global index indicate excellent correlation degrees of the variables, all close to 0.9 . Namely, there is a strong relation, considering that 1 is the perfect correlation value. SIMCE variable is the one that obtains the highest correlation, followed by Teacher Evaluation and finally, Student-Teacher ratio that equally have a good correlation degree (Table 8).

\section{Discussion and Conclusions: Characterization of the Spatial Inequity in the CMA}

Results already presented seem to confirm that there are significant differences in the spatial distribution of the pre-university schools in the CMA area and, therefore, notable contrasts in the access to this kind of facilities, especially if we consider the access to quality schools. Moran's I spatial auto-correlation analysis has become a valuable method to know and prove the situation of every territorial unit, in relation to the other geographic surrounding entities, indicating the dissimilar spatial configuration of the educational facilities within the territory.

Identifying spatial inequity patterns in educational issues is generally grounded on a specialized description of both coverage and quality of the service (estimated on teacher competence indicators and/or academic performance). Nevertheless, in many studies the correlation between these indicators and those of environmental quality and/or socioeconomic level is ignored (Talen, 2001). Likewise, the location of such schools is apparently unresponsive to a logical inclusive territorial planning (Pitarch Garrido, 2000).

In the CMA, educational quality is presented unequally. Specifically, the most disadvantaged places are located in Tomé, Hualpén, some places in San Pedro de la Paz, Coronel, Lota and Santa Juana. The singularity of this case is that most of its population belongs to low socioeconomic classes. Thus, the gap among different zones has a strong spatial relation between geographic distance and educational quality, as well as a notorious downtown - periphery spatial pattern and providing clearly differentiated social benefits. Distance becomes in a factor that clearly determines the access to quality facilities, especially damaging lower socioeconomic strata and moving in detriment to a desirable equity and social cohesion.

From the methodological point of view, the analyses used have allowed us to describe both distribution and spatial coverage of these facilities and their relation with the distribution of the demand and with some parameters of quality usually used by the Chilean Ministry of Education. However, this first approach opens gates to multiple questions. We could ask, for example: What other components and factors would be relevant 
Table 8.

Moran variables of educational quality.

\begin{tabular}{cc}
\hline Indicator & I Moran \\
\hline SIMCE & 0.9721 \\
Teacher evaluation & 0.9554 \\
Student-teacher ratio & 0.9531 \\
\hline
\end{tabular}

to the performance of a full diagnose that was the basis of a solid spatial and sectoral planning? Are the gross enrolment rates, the amount of square meters built, the computer resources per facility, the origin of students or the transportation the way to reach downtown $\cdots$ ?

Without a doubt it would be of interest to know the distance travelled (such as average, maximum and minimum distances and typical deviations), point of origin and destination of the students in order to allow drawing spider-maps for the different municipalities and kind of school (per type of financing and/or educational quality indices) and establish, thus, the deficits in certain areas or the degree of competence among centers (Table 9).

If the weight of private funding seems to be behind of an important part of the unequal spatial distribution of the resources and schools, it would be advisable to enquire into the most appropriate way of establishing a correlation between characteristics of the centers and the surrounding socioeconomic conditions (Tolen, 2001).

Because the distribution pattern of the cities always locates low socioeconomic strata in degraded sectors, it is precisely those places which exhibit a greater amount of low quality educational facilities. This highlights the presence of a sociospatial problem, much more complex than the shortcomings presented by an educational facility, but closely related to the recovering of social and economic gaps that originate inequalities.

Undoubtedly, it is extremely difficult to establish a balance between supply and demand of services established by the inhabitants of a territory. However, the posed analyses even having an exploratory nature conforms a useful tool for the territorial planning, because educational facilities have in the city an integrative and space structuring role (Salado, 2012).

The case of spatial equity as inspiring principle that pretends that the whole population can have the same opportunities to access an educational service or at lest, these opportunities are excessively big, is truncated by the same public administration, generating a differential accessibility by different population groups, namely an unequal spatial distribution due to the concentration of good quality educational service in specific zones of the CMA. By uncovering the socio-spatial inequality in the CMA by means of the distribution of the educational facilities, this kind of analysis can become a useful tool for urban planning, because facilities have an integrative and space structuring role in the city. Educational institutions include organized actions of scientific and professional nature in order to reach the harmonic and sustainable development of the territory. Therefore, we must consider diagnosis as the basis of the territorial planning. This clarifies the past, present and future territorial system features, as well as their possibilities of evolution as a result of maintaining current conditions.

Therefore, as it has previously indicated, it becomes fundamental to carry out the analysis of the SIMCE results taking
Table 9.

Population and schools by commune, according to financing type.

\begin{tabular}{cccccccccc}
\hline \multirow{2}{*}{ Commune } & $\begin{array}{c}\text { Population } \\
2012 \\
\text { (inhabitants) }\end{array}$ & \multicolumn{2}{l}{ Municipal } & \multicolumn{2}{c}{ Subsidized } & \multicolumn{2}{c}{ Particular } & \multirow{2}{*}{$\mathrm{N}^{\mathrm{o}}$} \\
\cline { 3 - 7 } & & $\mathrm{N}^{\mathrm{o}}$ & $\%$ & $\mathrm{~N}^{\circ}$ & $\%$ & Total \\
\hline Concepción & 214.234 & 42 & 35.9 & 61 & 52.1 & 14 & 12.0 & 117 \\
Talcahuano & 150.881 & 37 & 52.9 & 31 & 44.3 & 2 & 2.9 & 70 \\
$\begin{array}{c}\text { San Pedro de } \\
\text { la Paz }\end{array}$ & 121.655 & 10 & 23.3 & 28 & 65.1 & 5 & 11.6 & 43 \\
Chiguayante & 84.880 & 10 & 23.3 & 27 & 62.8 & 6 & 14.0 & 43 \\
Penco & 46.261 & 15 & 62.5 & 9 & 37.5 & 0 & 0.0 & 24 \\
Tomé & 54.508 & 34 & 89.5 & 4 & 10.5 & 0 & 0.0 & 38 \\
Coronel & 108.855 & 27 & 48.2 & 29 & 51.8 & 0 & 0.0 & 56 \\
Lota & 48.687 & 15 & 55.6 & 12 & 44.4 & 0 & 0.0 & 27 \\
Hualpén & 92.530 & 15 & 65.2 & 7 & 30.4 & 1 & 4.3 & 23 \\
Hualqui & 23.030 & 22 & 78.6 & 6 & 21.4 & 0 & 0.0 & 28 \\
Santa Juana & 13.201 & 23 & 95.8 & 1 & 4.2 & 0 & 0.0 & 24 \\
\hline
\end{tabular}

Note: Source: INE 2012 and MINEDUC data base, 2011.

into account the socioeconomic group, because it represents one of the main variables associated to learning achievements of the students.

\section{Acknowlegements}

The authors are grateful for funding provided by the Centro de Desarrollo Urbano Sustentable (CEDEUS), Conicyt/Fondap/ 15110020 .

This research has benefited from a collaboration within the framework of the "TRANSendaNC" project, an International Research Staff Exchange Scheme (IRSES) under the FP7 program.

\section{REFERENCES}

Benson, J. S. (2001). The impact of privatization on access in Tanzania, Social Science \& Medicine, 52, 1903-1915. http://dx.doi.org/10.1016/S0277-9536(00)00308-7

Bissonnette, L., Wilson K., Bell, S., \& Shah, T. I. (2012). Neighbourhoods and potential access to health care: The role of spatial and spatial factors, Health \& Place, 18, 841-853. http://dx.doi.org/10.1016/j.healthplace.2012.03.007

Bosque, J., \& Moreno, A. (2004). Sistemas de Información Geográfica, \& localización de instalaciones, \& equipamientos. Madrid: España, Ra-Ma.

Bosque, J., \& Moreno, A. (2005). Localización-asignación, \& justicia/equidad espacial con sistemas de información geográfica. Memorias. XI Conferencia Iberoamericana de SIG Lujan, Universidad de Luján, 95-115.

Buzai, G., \& Baxendale, C. (2008). Clasificación de unidades espaciales mediante indicadores de planificación. Teoría método, \& aplicación. Anuario de la División Geografía 2007, Universidad Nacional de Luján, 21.

Buzai, G., \& Pineda, M. C. (2007). Estructura socioespacial de la República de Honduras. Revista de Geografía, 11, 13-28.

CASEN (2006). Encuesta de Caracterización Socioeconómica Nacional. Ministerio de Desarrollo Social. Gobierno de Chile. www.casen.cl. 
Celemin, J. P. (2009). Autocorrelación espacial e indicadores locales de asociación espacial. Importancia, estructura, \& aplicación. Revista Universitaria de Geografía, 18, 11-31.

Cervigni, F., Suzuki, Y., Ishii, T., \& Hata, A. (2008). Spatial accessibility to pediatric services. Journal of Community Health, 33, 444-448. http://dx.doi.org/10.1007/s10900-008-9112-x

Cheng, Y., Wang, J., \& Rosenberg, M. W. (2012). Spatial access to residential care resources in Beijing, China. International Journal of Health Geographics, 11, 32-43. http://dx.doi.org/10.1186/1476-072X-11-32

Departamento Administrativo de Educación Municipal (2011). Plan Anual de Educación Municipal (PADEM).

Escolano, S., Ruiz, E., \& Climent, E. (2005). Red de centros educativos, $\&$ desequilibrios territoriales: El caso de Aragón. Geographicalia, 47, 153-176.

Flores, V. (2009). Localización de instalaciones no deseables: Aportes desde la geografía a la instalación de rellenos sanitarios en el Área Metropolitana de Concepción. Tesis para optar al título de Geógrafo. Concepción: Universidad de Concepción, 128.

Fuenzalida, M. (2010). Análisis de desigualdad territoriales en la oferta de equipamientos públicos: El caso de los hospitales en la red asistencial del sistema público de salud en Chile. Geografía, \& Sistemas de Información Geográfica, 2, 111-125.

Fundación para la Superación de la Pobreza (2006). Umbrales sociales 2006. Propuesta para la futura política social. Santiago, 13.

Góngora Gómez, J. (2007). Dimensión espacial de las remesas de migrantes internacionales en México. Tesis para optar al título de Maestro en estudios de población, \& desarrollo regional.

Cuernavaca, M. (2007). Universidad Autónoma del Estado de Morelos, 105.

Goodchild, M., \& Haining, S. (1992). Integrating GIS and spatial data analysis problem and possibilities. Geographical Information Systems, 6, 407-423. http://dx.doi.org/10.1080/02693799208901923

GORE/UGIT-Gobierno Regional Región del Bío Bío/Unidad de Gestión de Información Territorial (2011). Información georreferenciada, Unidad de Gestión de Información Territorial. Gobierno Regional del Bío Bío.

Gualiardo, M. F. (2004). Spatial accessibility of primary care: Concepts, methods and challenges. International Journal of Health Geographics, 3, 1-13. http://dx.doi.org/10.1186/1476-072X-3-1

Gutiérrez, J., \& García, J. (2002). Accesibilidad peatonal a la red sanitaria de asistencia primaria en Madrid. Anales de Geografía de la Universidad Complutense, 269-280.

Gutiérrez, J., \& García, J. (2005). Cambios en la movilidad en el área metropolitana de Madrid: El creciente uso del transporte privado. Anales de Geografía de la Universidad Complutense de Madrid, 25, 331-351.

Gutiérrez, J., Pinto, C., \& Gómez, G. (2000). Accesibilidad peatonal a la red de metro de Madrid: Efectos del plan de ampliación 1995-99. Anales de Geografía de la Universidad Complutense, 20, 451-464.

Harvey, D. (1977). Urbanismo, \& desigualdad social. Madrid. España, Siglo: XXI Editores S.A.

INE-Instituto Nacional de Estadísticas (2002). XVII CENSO de población, \& VI de vivienda. Gobierno de Chile. www.ine.cl.

INE-Instituto Nacional de Estadísticas (2012). XVII CENSO de población, \& VII de vivienda. Gobierno de Chile. www.ine.cl.

Langford, M., Higgs, G., Radcliffe, J., \& White, S. (2008). Urban population distribution models and service accessibility estimation, Computers. Environment and Urban Systems, 32, 66-80. http://dx.doi.org/10.1016/j.compenvurbsys.2007.06.001

Lee, J., \& Wong, D. (2001). Statistical analysis with ArcView GIS. New York: John Wiley and Sons.

López Hernández, F., \& Palacios Sánchez, M. A. (2000). Distintos modelos de dependencia espacial. Análisis de autocorrelación. Anales de Economía Aplicada. Oviedo, España, 1-17.

Luo, W. (2004). Using a GIS-based floating catchment method to assess areas with shortage of physicians. Health Place, 10, 1-11. http://dx.doi.org/10.1016/S1353-8292(02)00067-9

Luo, W., \& Qi, Y. (2009). An enhanced two-step floating catchment area (E2SFCA) method for measuring spatial accessibility to primary care physicians. Health Place, 15, 1100-1107. http://dx.doi.org/10.1016/j.healthplace.2009.06.002

Luo, W., \& Whippo, T. (2012). Variable catchment sizes for the two-step floating catchment area (2SFCA) method. Health Place, 18, 789-795. http://dx.doi.org/10.1016/j.healthplace.2012.04.002

MINEDUC-Ministerio de Educación (2010). Sistema de Medición de Calidad de la Educación (SIMCE). Gobierno de Chile. www.mineduc.cl.

MINEDUC-Ministerio de Educación (2011). Establecimientos Educativos en la Región del Bío Bío. Gobierno de Chile. www.mineduc.cl.

Ministerio de Educación-Departamento de estudios y desarrollo de la División de Planificación y Presupuesto (2008). Indicadores de la Educación en Chile 2007-2008. Estudios y estadísticas del sistema del escolar chileno, 5, 140.

Moreno, A. (1999). Justicia y eficiencia espacial como principios para la planificación: Aplicación en la provisión de servicios colectivos con SIG. IX Conferencia Iberoamericana de Sistemas de Información Geográfica, 197-230.

Moreno, A. (2007). En torno a los conceptos de equidad, justicia e igualdad especial. Huellas, 11, 133-142.

Oberty, M. (2007). Social and school differentiation in urban space: Inequalities and local configurations. Environment and Planning A, 39, 208-227. http://dx.doi.org/10.1068/a39159

Organisation for Economic Co-operation and Development, OECD (2012). Education at a Glance 2012: OECD Indicators, OECD Publishing. URL (last checked 10 Jan 2012).

http://dx.doi.org/10.1787/eag-2012-en http://dx.doi.org/10.1787/eag-2012-en

Pitarch Garrido, M. D. (2000). Los modelos de planificación espacial de los servicios públicos: El caso de los servicios educativos. Cuadernos de Geografía, 67-68, 119-136.

Pizzolato, N., Broseghini, F., \& Noguera, L. (2004). School location methodology in urban areas of developing countries. International Transactions in Operational Research, 11, 667-681. http://dx.doi.org/10.1111/j.1475-3995.2004.00483.x

Ramírez, L. (2008). Estudio de la accesibilidad de la población del Gran Resistencia a los centros de salud. Serie Geográfica, 14, 235 248.

Rojas, C., Muñiz, I., \& Pino, J. (2013). Understanding the urban sprawl in the mid-size Latin American cities through the urban form: Analysis of the concepcion metropolitan area (Chile). Journal of Geographic Information System, 5, 222-234. http://dx.doi.org/10.4236/jgis.2013.53021

Sabatini, F., \& Brain, I. (2008). La segregación, los guetos y la integración social urbana: Mitos y claves. Revista latinoamericana de estudios urbanos regionales EURE (Santiago), 34, 5-26.

www.scielo.cl/scielo.php?script=sci_arttext\&pid=S0250-716120080 00300001\&lng=es\&nrm=iso.

Sabuda, F. (2007). Autocorrelación espacial aplicada al análisis de la vulnerabilidad educativa en la ciudad de Mar del Plata. XI Conferencia Iberoamericana de Sistema de Información Geográfica, Buenos Aires, Argentina, 20.

Sabuda, F., Ares, S., \& Mikkelsen, C. (2005). Calidad de vida y accesibilidad geográfica en la ciudad de Mar del Plata, primeros aportes (pp. 1-7). Mar del Plata, Argentina: X Jornadas Argentinas de Estudios de Población.

Salado, M. J. (2012). Localización de los equipamientos colectivos, accesibilidad y bienestar social, en Bosque, J. y Moreno, A. (coords): Sistemas de Información Geográfica y localización óptima de instalaciones y equipamientos ( $2^{\mathrm{a}}$ ed.). Madrid, España: Ra-Ma, Revisada y ampliada, 41-65.

Talen, E. (2001). School, community and spatial equity: An empirical investigation of access to elementary schools in West Virginia. Annals of the Association of American Geographers, 91, 465-486. http://dx.doi.org/10.1111/0004-5608.00254

Tsou, K. W., Hung, Y. T., \& Chang, Y. L. (2005). An accessibilitybased integrated measure of relative spatial equity in urban public facilities. Cities, 22, 424-435. http://dx.doi.org/10.1016/j.cities.2005.07.004

Villanueba, A. (2010). Accesibilidad geográfica a los sistemas de salud y educación. Análisis espacial de las localidades de Necochea y Quequén. Revista Territorio y Transporte, 2, 23. 


\section{H. DE LA FUENTE ET AL.}

Wang, F. H. (2012). Measurement, optimization, and impact of health care accessibility: A methodological review. Annals of the Association of American Geographers, 102, 1104-1112.

http://dx.doi.org/10.1080/00045608.2012.657146
Yi, L. (2004): Evaluation of accessibility to primary schools. The case of Yuhua, Changsha, China (p. 81). Tesis para optar al título de master of science in urban planning and land administration. Enschede: Utrecht University and ITC. 